\title{
STUDY OF PLEURAL EFFUSIONS OF PANCREATIC AETIOLOGY IN A TERTIARY CARE CENTRE
}

\author{
Ramakrishna Rachakonda1, Kalyankumar P. V', M. Venu ${ }^{3}$
}

1 Professor and HOD, Department of Pulmonology, Katuri Medical College, Guntur. ${ }^{2}$ Associate Professor, Department of Pulmonology, Katuri Medical College, Guntur. ${ }^{3}$ Associate Professor, Department of Pulmonology, Katuri Medical College, Guntur.

\section{ABSTRACT}

\section{BACKGROUND}

We have studied seven cases of Pleural effusion of pancreatic aetiology from 2015 to 2017.

Aim of the Study- Alcoholism is increasing in our society and so are the pancreatic problems. Pleural effusions of pancreatic aetiology are also increasing in clinical practice. We intended to study the clinical presentation, alcoholic history and investigated the patients.

\section{MATERIALS AND METHODS}

Among cases of Pleural effusion admitted in Pulmonology and referred from Surgery Department for pulmonology consultation, we have identified and studied cases of pleural effusion of pancreatic aetiology. The diagnosis was confirmed by clinical examination, Ultrasonography of abdomen, CT examination in selective cases apart from routine haematology and biochemistry. Serum and Pleural fluid amylase and lipase, serum calcium and electrolytes.

\section{RESULTS}

All the seven patients are males. Age ranged from 29 to 54 years. All the seven patients gave alcoholic history ranging from 8 years to 30 years. Four patients presented with acute pancreatitis and three patients presented with chronic pancreatitis. Cough, epigastric pain and shortness of breath were symptoms. Two patients presented with right-sided effusions and two patients with left-sided effusions. Three patients had bilateral effusions. Only one patient had multiple gall stones. Only one patient had massive pleural fluid of amber coloured. Rest of the patients had straw coloured pleural fluid ranging from 400 mL to 1 litre. Leukocytosis was common with polymorphonuclear leukocytosis. All the patients showed elevation of serum and pleural fluid amylase. All but two patients showed increased pleural fluid amylase compared to serum amylase. All of them were stabilised and referred to Gastroenterology units.

\section{CONCLUSION}

Pleural effusion of pancreatic aetiology is not uncommon. All of our patients are males and alcoholics. A high degree of suspicion is needed, as the patients have more of abdominal symptoms. Serum and pleural fluid amylase and lipase are diagnostic. Treatment is conservative and ERCP and surgical approach may be needed in selected patients.

\section{KEYWORDS}

Pancreatic Pleural Effusions, Amylase, Lipase, ERCP (Endoscopic Retrograde Cholangiopancreaticography).

HOW TO CITE THIS ARTICLE: Rachakonda R, Kalyankumar PV, Venu M. Study of pleural effusions of pancreatic aetiology in a tertiary care centre. J. Evolution Med. Dent. Sci. 2017;6(47):3660-3663, DOI: 10.14260/Jemds/2017/789

\section{BACKGROUND}

Pleural effusions of Pancreatic aetiology are becoming increasingly common in India. A high degree of suspicion is needed, because the treatment is entirely different from the pleural effusions of infectious aetiology. Alcohol is consumed by many even from an young age and patients presenting with pancreatic pleural effusions gave long history of alcohol intake.

Non-malignant pancreatic pleural effusions can occur in acute pancreatitis, chronic pancreatitis, pancreatic pseudocyst and pancreatic ascites ${ }^{1}$ and most of the effusions are bilateral. The presence of pleural effusion in patients

Financial or Other, Competing Interest: None.

Submission 02-04-2017, Peer Review 31-05-2017,

Acceptance 05-06-2017, Published 12-06-2017.

Corresponding Author:

Dr. Ramakrishna Rachakonda,

Sanjeevani Hospital, A1,

Ramkuteer Majestic, 3/13,

Brodipet, Guntur.

E-mail: ramakrishna45@yahoo.co.in

DOI: $10.14260 /$ jemds $/ 2017 / 789$

\section{(c) (i) $(5)$}

with acute pancreatitis is an indication of more severe pancreatitis. ${ }^{2}$ Pancreatic pseudocyst occurred in nearly a third of the patients with pancreatic pleural effusions. ${ }^{3}$

The exudative pleural effusions in acute pancreatitis result from the transdiaphragmatic transfer of the exudative fluid arising from acute pancreatic inflammation and from diaphragmatic inflammation. ${ }^{1}$ Lymphatic communication between pleural and peritoneal lymphatics transfers inflammatory fluid rich in pancreatic enzymes and can cause more exudation into the pleural space. ${ }^{1}$ Acute abdominal symptoms dominate in acute pancreatitis and sometimes chest symptoms may mimic pleuritic chest pain and pneumonia. Untreated acute pancreatitis can lead to pseudopancreatic cyst or pancreatic abscess.

Serum amylase and lipase are elevated and pleural fluid levels are often more than serum levels. Levels of serum and pleural fluid amylase are higher in chronic pancreatitis than acute. Pleural fluid in such condition is usual and exudates with high white cell count ranging from 10000 to 50000 with increased neutrophils. ${ }^{4}$ In patients of pancreatic pleural effusions, pancreatic pseudocyst or abscesses must be 
excluded with the help of Ultrasonography or CT scan. These complications have high mortality. ${ }^{5}$ Most patients with chronic pancreatic pleural effusion are men. In more than $90 \%$ of male patients, the pancreatic disease is a result of alcoholism. ${ }^{6}$ Patients with chronic pancreatic pleural effusion have more chest symptoms, because of decompression of pseudocyst. Pleural effusion is predominantly left-sided or bilateral. ${ }^{6}$

\section{MATERIALS AND METHODS}

We have investigated patients of pleural effusion having history of alcoholism and abdominal symptom and analysed the pleural fluid. We had a total of 7 patients who fitted into the category of pancreatic pleural effusions. They were all negative for malignancy.

\section{Investigations Done}

Complete CBP, ESR, Hb, urine routine, blood sugar, urea, $\mathrm{S}$. creatinine, C-reactive protein, U/S abdomen, Serum LDH, S. lipase, S. amylase, pleural fluid amylase and lipase, serum calcium, and ABG.

\section{RESULTS}

We have seven cases of pleural effusion among the patients presenting to Pulmonology Department or referred to us during two years. All the patients are males. Age ranged from 29 to 54 years. Three patients among seven had recurrent pancreatitis. Four patients were diagnosed to have acute pancreatitis for the first time. One patient had pseudopancreatic cyst by ultrasound abdomen and one patient had pancreatic fibrosis. Pleural fluid was exudates in all the patients by Light's criteria. Among our patients of study two patients had right-sided effusions, two patients had left-sided effusions and three patients had bilateral effusions.

All of them gave the history of alcoholism. One patient had high serum triglycerides and had gallstones. One patient was found to be diabetic and he was an occasional alcoholic presenting to Department of Surgery. He had mild azotaemia at the time of presentation with increased triglycerides and multiple gall stones. Serum calcium levels ranged between $7.7 \mathrm{mg} \%$ to $9.5 \mathrm{mg} \%$.

Serum amylase and pleural fluid amylase were raised in all the patients. Pleural amylase was more than serum amylase in all but two subjects of our study. Ultrasound abdomen is helpful in the diagnosis. Abdominal symptoms were more common among all the patients. One patient had only abdominal symptoms and no chest symptoms and was diagnosed by chest x-ray.

The first patient in our study was a 29-year-old male with 8 years of history of heavy alcohol intake. The patient presented with shortness of breath, cough and abdominal symptoms. He presented with massive pleural effusion and we put intercostal tube drainage. The fluid was amber coloured like Coca Cola. All the patients were managed symptomatically with antibiotics, Proton pump inhibitors, IV fluids, calcium and supportive drugs. Pleural aspiration was done to relieve the symptoms. They were referred to units of gastroenterology for medical and surgical treatment.

\begin{tabular}{|c|c|c|c|c|c|c|c|c|}
\hline $\begin{array}{c}\text { Sl. No. } \\
\text { of } \\
\text { Patient }\end{array}$ & Age & Sex & $\begin{array}{c}\text { H/O } \\
\text { Alcohol }\end{array}$ & $\begin{array}{l}\text { Pancreatic } \\
\text { State }\end{array}$ & $\begin{array}{c}\mathrm{U} / \mathrm{S} \\
\text { Abdomen }\end{array}$ & $\begin{array}{c}\text { Serum } \\
\text { Amylase }\end{array}$ & $\begin{array}{c}\text { Side of } \\
\text { Pleural } \\
\text { Fluid }\end{array}$ & $\begin{array}{c}\text { Pleural } \\
\text { Fluid } \\
\text { Amylase }\end{array}$ \\
\hline 1. & $\begin{array}{c}29 \\
\text { Years }\end{array}$ & male & Yes, 8 Years & $\begin{array}{c}\text { Recurrent } \\
\text { Pancreatitis }\end{array}$ & $\begin{array}{c}\text { Inflammation of } \\
\text { Pancreas }\end{array}$ & $1000 \mathrm{IU} / \mathrm{L}$ & Right & $1600 \mathrm{IU} / \mathrm{L}$ \\
\hline 2. & $\begin{array}{c}46 \\
\text { Years }\end{array}$ & Male & Yes, 20 Years & $\begin{array}{c}\text { Recurrent } \\
\text { Pancreatitis }\end{array}$ & $\begin{array}{c}\text { Pseudopancreatic } \\
\text { Cyst }\end{array}$ & $727 \mathrm{IU} / \mathrm{L}$ & Left & $1727 \mathrm{IU} / \mathrm{L}$ \\
\hline 3. & 44 Years & Male & Yes, 21 Years & Acute Pancreatitis & Acute Pancreatitis & $964 \mathrm{IU} / \mathrm{L}$ & Bilateral & $1102 \mathrm{IU} / \mathrm{L}$ \\
\hline 4. & 54 Years & Male & Yes, 30 Years & $\begin{array}{c}\text { Recurrent } \\
\text { Pancreatitis }\end{array}$ & Pancreatic Fibrosis & $624 \mathrm{IU} / \mathrm{L}$ & Right & $450 \mathrm{IU} / \mathrm{L}$ \\
\hline 5. & 39 Years & Male & Yes, 9 Years & Acute Pancreatitis & Acute Pancreatitis & $1100 \mathrm{IU} / \mathrm{L}$ & Left & $1654 \mathrm{IU} / \mathrm{L}$ \\
\hline 6. & 42 Years & Male & 16 , Years & Acute Pancreatitis & Acute Inflammation & $604 \mathrm{IU} / \mathrm{L}$ & Bilateral & $1650 \mathrm{IU} / \mathrm{L}$ \\
\hline 7. & 50 Years & Male & $\begin{array}{c}\text { Only } \\
\text { Occasional } \\
\text { Alcohol }\end{array}$ & $\begin{array}{c}\text { Acute } \\
\text { Pancreatitis }\end{array}$ & Acute & $804 \mathrm{IU} / \mathrm{L}$ & Left & $670 \mathrm{IU} / \mathrm{L}$ \\
\hline
\end{tabular}

\begin{tabular}{|c|c|c|}
\hline Sl. No. & $\begin{array}{c}\text { Serum } \\
\text { Triglycerides }\end{array}$ & $\begin{array}{c}\text { Gallstones in the U/S } \\
\text { Abdomen }\end{array}$ \\
\hline 1. & $225 \mathrm{mg} \%$ & None \\
\hline 2. & $168 \mathrm{mg} \%$ & None \\
\hline 3. & $148 \mathrm{mg} \&$ & None \\
\hline 4. & $156 \mathrm{mg} \%$ & None \\
\hline 5. & $220 \mathrm{mg} \%$ & None \\
\hline 6. & $196 \mathrm{mg} \%$ & None \\
\hline 7. & $296 \mathrm{mg} \%$ & Multiple Gall stones \\
\hline \multicolumn{3}{|c|}{ Table 2. Serum Triglycerides and } \\
Gallstones by Ultrasonography
\end{tabular}

\begin{tabular}{|c|c|c|c|}
\hline $\begin{array}{c}\text { Sl. No. of } \\
\text { Patient }\end{array}$ & $\begin{array}{c}\text { Fasting Blood } \\
\text { Sugar } \mathbf{~ m g \%}\end{array}$ & $\begin{array}{c}\text { Blood Urea } \\
\mathbf{m g \%}\end{array}$ & $\begin{array}{c}\text { Serum } \\
\text { Creatinine } \mathbf{~ m g \%}\end{array}$ \\
\hline 1. & 96 & 34 & $1.3 \mathrm{mg} \%$ \\
\hline 2. & 101 & 44 & 1.1 \\
\hline 3. & 77 & 38 & 0.9 \\
\hline 4. & 96 & 24 & 0.9 \\
\hline 5. & 113 & 33 & 1.5 \\
\hline 6. & 107 & 41 & 1.4 \\
\hline 7. & 156 & 44 & 1.6 \\
\hline \multicolumn{4}{|c|}{ Table 3. Biochemical Profile } \\
\hline
\end{tabular}




\begin{tabular}{|c|c|c|}
\hline Sl. No. & Symptoms & Pleural Fluid \\
\hline 1. & $\begin{array}{c}\text { Cough, breathlessness, abdominal pain, H/O similar } \\
\text { symptoms before }\end{array}$ & Massive fluid occupying entire hemithorax \\
\hline 2. & SOB, abdominal pain & $700 \mathrm{cc} \mathrm{by} \mathrm{U/S}$ \\
\hline 3. & Epigastric pain & $450 \mathrm{cc}$ \\
\hline 4. & $\begin{array}{c}\text { Epigastric and abdominal } \\
\text { pain, cough SOB }\end{array}$ & $200 \mathrm{cc}$ \\
\hline 5. & Acute abdominal pain & $1 \mathrm{~L}$ \\
\hline 6. & $\begin{array}{c}\text { Abdominal pain, } \\
\text { cough and SOB }\end{array}$ & $600 \mathrm{~mL}$ on left side, \\
\hline 7. & $\begin{array}{c}\text { Only abdominal pain, } \\
\text { no chest symptoms }\end{array}$ & $400 \mathrm{~mL}$ on right side \\
\hline & Table 4. Clinical Symptoms and Quantity of Pleural fluid \\
\hline
\end{tabular}

\begin{tabular}{|c|c|c|c|c|}
\hline Sl. No. & Total Count & Polymorphs \% & ESR & Hb\% \\
\hline 1. & 16000 & $79 \%$ & $69 \mathrm{~mm} / \mathrm{hr}$ & $64 \%$ \\
\hline 2. & 14500 & $80 \%$ & 74 & $62 \%$ \\
\hline 3. & 10900 & $56 \%$ & $60 \mathrm{~mm}$ & $65 \%$ \\
\hline 4. & 14500 & $66 \%$ & 59 & $53 \%$ \\
\hline 5. & 11450 & $70 \%$ & 92 & $60 \%$ \\
\hline 6. & 9700 & $72 \%$ & 45 & $70 \%$ \\
\hline 7. & 6300 & $54 \%$ & \\
\hline
\end{tabular}

\begin{tabular}{|c|c|c|c|c|}
\hline l. No. & $\begin{array}{c}\text { Pleural } \\
\text { Fluid Cells }\end{array}$ & Glucose & Proteins & Serum Lipase \\
\hline $\begin{array}{l}\text { 1. Amber Coloured, } \\
\text { 2. Resembling Coca Cola }\end{array}$ & 22000/Cumm & $84 \mathrm{mg} \%$ & $3.5 \mathrm{~g} \%$ & Elevated $464 \mathrm{IU} / \mathrm{L}$ \\
\hline 3. Straw Coloured & 19000/Cumm & $156 \mathrm{mg} \%$ & $4.2 \mathrm{~g} \%$ & $504 \mathrm{IU} / \mathrm{L}$ \\
\hline 4. Straw Coloured & 1200/Cumm & $102 \mathrm{mg} \%$ & $3.1 \mathrm{~g} \%$ & $432 \mathrm{IU} / \mathrm{L}$ \\
\hline 5. Straw Coloured & 5600/Cu.mm & $77 \mathrm{mg} \%$ & $3.6 \mathrm{~g} \%$ & $532 \mathrm{IU} / \mathrm{L}$ \\
\hline 6. Straw Coloured & 1700/Cumm & $122 \mathrm{mg} \%$ & $2.9 \mathrm{~g} \%$ & $442 \mathrm{IU} / \mathrm{L}$ \\
\hline 7. Straw Coloured & 2700/Cumm & $98 \mathrm{mg} \%$ & $3.6 \mathrm{~g} \%$ & $533 \mathrm{IU} / \mathrm{L}$ \\
\hline 8. Haemorrhagic & 11000/Cumm & $224 \mathrm{mg} \%$ & $3.4 \mathrm{~g} \%$ & $604 \mathrm{IU} / \mathrm{L}$ \\
\hline
\end{tabular}

\begin{tabular}{|c|c|c|c|}
\hline Sl. No. & Procedure & Management & Followup \\
\hline 1. & ICT drain & Conservative & $\begin{array}{c}\text { Referred to Higher } \\
\text { Centre for ERCP }\end{array}$ \\
\hline 2. & $\begin{array}{c}\text { Pleural } \\
\text { aspiration }\end{array}$ & Conservative & $\begin{array}{c}\text { Referred to } \\
\text { Gastroenterologist }\end{array}$ \\
\hline 3. & $\begin{array}{c}\text { Pleural } \\
\text { aspiration }\end{array}$ & Conservative & $\begin{array}{c}\text { Referred to } \\
\text { Gastroenterologist }\end{array}$ \\
\hline 4. & $\begin{array}{c}\text { Pleural } \\
\text { aspiration }\end{array}$ & Conservative & $\begin{array}{c}\text { Referred to } \\
\text { Gastroenterologist }\end{array}$ \\
\hline 5. & $\begin{array}{c}\text { Pleural } \\
\text { aspiration }\end{array}$ & Conservative & $\begin{array}{c}\text { Referred to } \\
\text { Gastroenterologist }\end{array}$ \\
\hline 6. & $\begin{array}{c}\text { Pleural } \\
\text { aspiration }\end{array}$ & Conservative & $\begin{array}{c}\text { Referred to } \\
\text { Gastroenterologist }\end{array}$ \\
\hline 7. & $\begin{array}{c}\text { Pleural } \\
\text { aspiration }\end{array}$ & Conservative & $\begin{array}{c}\text { Patient was in the } \\
\text { Surgery Department }\end{array}$ \\
\hline \multicolumn{3}{|c|}{ Table 7. Mode of Management } \\
\hline
\end{tabular}

\section{DISCUSSION}

Dr. Sumalatha et al presented similar observations in their study of four patients and one of them had pancreatic malignancy. No malignancy was found in our study. ${ }^{7}$ Joseph J et $\mathrm{al}^{8}$ found $25 \%$ of cases of amylase rich pleural effusion among 200 patients studied and $16 \%$ of them had evidence of pancreatitis. They opined that malignancy is a significant cause of non-pancreatic amylase rich effusions. KB Gupta et $\mathrm{al}^{9}$ stressed the importance of measurement of isoenzymes of amylase in amylase rich effusions. They found that increased pleural fluid: Serum Amylase ratio of $>1$ should indicate the possibility of malignancy. Bedi RS ${ }^{10}$ showed in their case report that massive haemorrhagic pleural effusion rich in amylase should warrant the existence of chronic pancreatitis. Mark Z Simmons et al ${ }^{11}$ suggested the importance of CT scan of abdomen in identifying minimum pleural effusions in patients with acute pancreatitis and having history of alcohol intake. Anil Sontakke, BO Tayade et $\mathrm{al}^{12}$ in their study stressed the importance of studying early serum and pleural fluid amylase and the importance of CT scan and ERCP.

\section{CONCLUSION}

Pleural effusion of pancreatic aetiology is not uncommon because of increased habit of alcohol intake in our society. Patients presented with long years of heavy alcohol intake. They were all diagnosed by increased pleural fluid and serum amylase levels assisted by clinical and ultrasonography. High degree of suspicion is required in diagnosing these cases, as pancreatic pleural effusions occur in patients with severe pancreatic disease. They may be associated with 
pseudopancreatic cyst and pancreatic abscess. If not diagnosed and treated, these problems may lead to increased mortality. All the middle-aged males presenting with pleural effusion and abdominal pain must be investigated, particularly those having history of alcohol intake.

\section{REFERENCES}

[1] Light RW. Exudative pleural effusions secondary to gastrointestinal diseases. Clin Chest Med. 1985;6(1):103-11.

[2] Heller SJ, Noordhoek E, Tenner SM, et al. Pleural effusion as a predictor of severity in acute pancreatitis. Pancreas 1997;15(3):222-5.

[3] Ramesh H, Kuruvilla K. Pleural effusions: a new negative prognostic parameter for acute pancreatitis. Am J Gastroenterol 1995;90(10):1898-9.

[4] Light RW, Ball WC. Glucose and amylase in pleural effusions. JAMA 1973;225(3):257-60.

[5] Miller TA, Lindenauer SM, Frey CF, et al. Proceedings: pancreatic abscess. Arch Surg 1974;108(4):545-51.

[6] Rockey DC, Cello JP. Pancreaticopleural fistula. Report of 7 patients and review of the literature. Medicine 1990;69(6):332-44.
[7] Sumalatha C. Right sided massive haemorrhagic pancreatic pleural effusions. International Journal of Current Research 2016;8(7):34198-200.

[8] Joseph J, Viney S, Beck P, et al. A prospective study of amylase-rich pleural effusions with special reference to amylase isoenzyme analysis. Chest 1992; 102(5): 1455-9.

[9] Gupta KB, Ghalaut V, Gupta R, et al. Estimation of serum and pleural fluid amylase and iso-enzyme in cases of malignant pleural effusion. Ind $\mathrm{J}$ Tub 2001;48:87.

[10] Bedi RS. Massive pleural effusion due to asymptomatic pancreatic disease. Lung India 2006;23(4):163-4.

[11] Simmons MZ, Miller JA, Zurlo JV, et al. Pleural effusions associated with acute pancreatitis: incidence and appearance based on computed tomography. Emergency Radiology 1997;4(5):287-9.

[12] Sontakke A, Tayade B0. Case series of pancreatic pleural effusion with pancreatico-pleural fistula. JIACM 2014;15(3-4):245-8. 